\title{
Socio-Economic Characteristics and Techniques of the Bee-Keeping in the Area of Goundi (Chad)
}

\author{
YA Issa ${ }^{1, *}$, D Rimadoumgue ${ }^{1}$, K Ardjoun ${ }^{1}$, M Tellah $^{1}$, and Y Mopate Logtene ${ }^{2}$ \\ ${ }^{1}$ Higher National Institute of Sciences and Technology of Abéché (INSTA), Abéché (Chad) \\ ${ }^{2}$ Institute of Research in Breeding for Development (IRED), Djaména (Chad)
}

*Corresponding author: YA Issa, Higher National Institute of Sciences and Technology of Abéché (INSTA), Abéché (Chad), Tel: (+235) 66 26 72 26; E-mail: issayou@gmail.com

Received: 26 Jul, 2019 | Accepted: 20 Aug, 2019 | Published: 28 Aug, 2019

Citation: Issa YA, Rimadoumgue D, Ardjoun K, Tellah M, Logtene YM (2019) Socio-Economic Characteristics and Techniques of the Bee-Keeping in the Area of Goundi, Chad. J Anim Sci Res 3(3): dx.doi.org/10.16966/2576-6457.131

Copyright: (C) 2019 Issa YA, et al. This is an open-access article distributed under the terms of the Creative Commons Attribution License, which permits unrestricted use, distribution, and reproduction in any medium, provided the original author and source are credited.

\section{Abstract}

The study is related to the socio-economic and technical characteristics of 101 keepers into 28 villages around Goundi suprefecture of Chad. It was carried out by investigation using a semi-structured questionnaire, direct interviews, and observations, from July to September 2016 . The results show that the bee-keeping is practised primarily by the men (99\%) 43.2 years old. More half $(53.5 \%)$ of the bee-keepers are Christians. They are the majority married $(94.1 \%)$ with $1.53 \pm 1.05$ women and had $7.59 \pm 6.140$ children. More than $52 \%$ of the bee-keepers are educated in primary school. Agriculture and breeding are the main activities of the bee-keepers. The average duration in the activity is of $13.18 \pm 10,18$ years and varies between 2 and 54 years. The aim of the breeding is for sale and subsistence farming (100\%). The colonies of bees are high in an extensive way. They belong to the Apis species Mellifera adansonii (yellow bee). The bee-keepers are using the traditional hives with little capacity (6.13 liters) of which the number varies from 1 to 304 hives, with an average of 17 hives per bee-keeper. Honey is the principal collected product. The average quantity of collected honey varies from 3 to 22 liters per colony. The annual production out of honey is on average $862.72 \pm 1859.26$ liters per bee-keeper. The average selling price of honey is 1676,57 FCFA the liter. The annual average income gross by bee-keeper is of 834,930 FCFA. The production of honey increases absolutely by the change of the practices of production through the framing, the training and to assist the bee-keepers.

Keywords: Bee-keeping; Characteristic-Socio-economic - Techniques; Goundi; Chad

\section{Introduction}

In sub-Saharan Africa, the products of the bee-keeping in particular honey, the wax and the propolis, play a significant role in the economy of the households and contribute to food safety [1]. The bees Melliferes play a role in the balance of the agricultural ecosystems and the maintenance of the vegetable biodiversity [2]. These pollinating insects, take part significantly in the improvement of the production and the productivity of the cultures $[3,4]$.

In the majority of the Sub-Saharan countries of Africa, the beekeeping is practised mainly in an extensive way. These countries, the majority of the bee-keepers exploit indigenous species of very low genetic potential. In spite of the richness of a Flora Mellifere extremely varied, the African bees produce only relatively small quantities of honey.

In Chad, the bee-keeping is localised primarily in the areas of Guerra, Salamat, the Moyen Chari and Mandoul. Unfortunately, a few studies were devoted to the bee-keeping in general and the practice production in particular.
The sub-prefecture of Goundi located to area of Mandoul was retained for the present study. This sub-prefecture is regarded as one of the great ecological zones of the country as regards production of honey. Indeed, the production of honey ensures food safety and gets considerable monetary incomes with the stockbreeders. The present study has like objective, to evaluate the socio-economic and technical characteristics of the bee-keeping of the zone of Goundi.

\section{Materials and Methods}

\section{Study site}

The choice of the area of study is justified by its significant potential of production of honey in Chad. It is regarded as the first apicole cattle-rearing area. Goundi is one of the three departments of the area of Eastern Mandoul and / is located at $58 \mathrm{~km}$ towards the North of the town of Koumra the population is estimated at 10052 inhabitants (RGPH2 2009). Agriculture, the breeding (in particular bee-keeping), the craft industry and the trade constitute the principal activities of the population. 
The annual average pluviometry of the area varies between 900 and $1300 \mathrm{~mm}$ annual. The vegetation consists of grown savanna mainly of type Parkia biglobosa, Vitellaria paradoxa, Khaya senegalensis, Prosopis africana, Tamarindus indica, Isoberlinia doka, Daniellia oliveri, Detarium microcarpum, etc.

\section{Sampling and data acquisition}

The study proceeded between 12th July and 19th August 2016 at random investigation control to 28 villages chosen randomly into the 80 villages which account the area (either a rate of a survey of $35 \%$ ).

On the whole, 101 bee-keepers were surveyed, using a questionnaire being used as guide of maintenance and compose of several parts carrying into the identification of the bee-keeper (name and first names, sex, matrimonial situation, a number of child, dependent, ethnics group, religion, level of schooling), the activities practised by the bee-keeper, the parameters of production, the practices of production, the control of the bees, the plants Melliferes used, the food practices, the exploitation of the products of hives, the performance of production, medical management as well as the constraints and the proposals for an improvement of the apicole breeding.

\section{Data analysis}

The collected data were seized in Excel and the various parameters were calculated using the software Statistical Package for the Social Science (SPSS, 2009). Collected information was synthesized expressed as a percentage and on average with standard deviations. Variables selected after a sorting flat were subjected to the variance analysis (ANOVA) with the test of multiple comparisons of Newmankeuls. The threshold of significance retained on the differences in average was $5 \%$.

\section{Results}

\section{Profile socio-economic of the bee-keepers}

The bee-keepers were essentially old men on average of $43.21 \pm$ 14.69 years with a minimum of 17 and one maximum 80 years. The average age of the men was significantly higher $(\mathrm{p}<0.05)$ that of the women. The principal activity of the bee-keepers was agriculture and breeding. The totality of the stockbreeders practised the bee-keeping for the sale, subsistence farming, and the gift. The majority of the beekeepers was married to $1.53 \pm 1.05$ wives and has $7.59 \pm 6.14$ children. And then, half has schooling of levels primary and secondary. Inquired was especially Christian or Muslim confession (Table 1). The average professional experiment in the activity was of $13.18 \pm 10.18$ years with a 2 years minimum and a 54 years maximum (Table 2).

\section{Types of hives and practical of bee-keeping}

The majority of the bee-keepers were used to the hollow tree trunk dead like hives (Table 3) among which, the majority of them were $(82.2 \%)$ arranged these deadwoods to be useful itself as hive counters approximately $17 \%$ which bought the same type of hive to the markets (Figure 1).

Nearly $70.3 \%$ of hives were used to small and average format against $29.7 \%$ of large size. The choice of hives was dictated by the accessibility and the output (Table 3). Branches of fruit trees and roofs of boxes, as well as the drill shafts, were the principal sites of hives (Figure 1) (Table 3).

\section{Control of the breeding}

The beekeepers were exclusively by the head of the household. They are ensuring controls and follow-up of the bees once every two days.
Table 1: Socio-economic profile of the bee-keepers.

\begin{tabular}{|c|c|c|c|}
\hline Parameters & States & Labour & P.100 (\%) \\
\hline \multirow{2}{*}{ Sex } & Man & 100 & 99 \\
\hline & Woman & 1 & 1 \\
\hline \multirow{3}{*}{ Religion } & Christian & 54 & 53.5 \\
\hline & Muslim & 45 & 44.6 \\
\hline & Animist & 2 & 2 \\
\hline \multirow{4}{*}{$\begin{array}{l}\text { Level of } \\
\text { Schooling }\end{array}$} & Primary & 52 & 51.5 \\
\hline & Illiterate & 37 & 36.6 \\
\hline & Secondary & 11 & 10.9 \\
\hline & Academic & 1 & 1 \\
\hline \multirow{2}{*}{$\begin{array}{l}\text { Matrimonial } \\
\text { situation }\end{array}$} & Married & 95 & 94.1 \\
\hline & Single & 6 & 5.9 \\
\hline $\begin{array}{l}\text { Principal } \\
\text { activity }\end{array}$ & Agriculture/élevage & 101 & 100 \\
\hline $\begin{array}{l}\text { Objective of } \\
\text { the breeding }\end{array}$ & $\begin{array}{l}\text { Sale, subsistence } \\
\text { farming, gift }\end{array}$ & 101 & 100 \\
\hline
\end{tabular}

Table 2: Parameters of production.

\begin{tabular}{|c|c|c|c|}
\hline Parameters & Answers & Labour & P.100 (\%) \\
\hline \multirow{3}{*}{ The bees species of the area } & 3 species & 63 & 63 \\
\hline & 2 species & 33 & 33 \\
\hline & 4 species & 4 & 4 \\
\hline \multirow{3}{*}{$\begin{array}{l}\text { Characteristics of species } \\
\text { most exploited bees }\end{array}$} & Small & 88 & 88 \\
\hline & Average & 11 & 11 \\
\hline & smaller & 1 & 1 \\
\hline Origin of the bees & Wild colonies & 101 & 100 \\
\hline \multirow{3}{*}{ Identification of the bees } & $\begin{array}{c}\text { Form, } \\
\text { aggressiveness }\end{array}$ & 53 & 52.5 \\
\hline & Forme bee & 36 & 35.6 \\
\hline & Color wing, wing & 12 & 11.9 \\
\hline Selection criteria & Output & 101 & 100 \\
\hline \multirow{4}{*}{$\begin{array}{l}\text { Method of acquisition of } \\
\text { colony }\end{array}$} & $\begin{array}{l}\text { Burn of wax in } \\
\text { the hive }\end{array}$ & 60 & 59.4 \\
\hline & Use of perfume & 31 & 30.7 \\
\hline & Use of onion wild & 7 & 6.9 \\
\hline & $\begin{array}{l}\text { Hole of the trees } \\
\text { and under ground }\end{array}$ & 3 & 3 \\
\hline
\end{tabular}

The renewal of colonies was practised by the majority of surveyed. It constituted the principal technique of maintenance of level of production at more half of the bee-keepers (Table 4).

\section{Melliferous plants used}

The flowers and nectars of natural plants in the area constituted the principal source of food of the bees. The most dominant plants were Vitellaria paradoxa, Parkia biglobosa, Khaya senegalensis, Daniella oliveri, Prosopis africana, Tamarindus indica, Detarium senegalense, Sorghum bicolor, Mangifera indica, Zea mays, etc (Table 5).

\section{Practical food}

The nourishment of colony, certain bee-keepers distributed formulated food. The distributed food was exclusively from cereales, onion, bean or peas of ground. The majority of surveyed considered that the bees were demanding out of water and food. The food complements were practised by most of the bee-keepers (Table 6). 

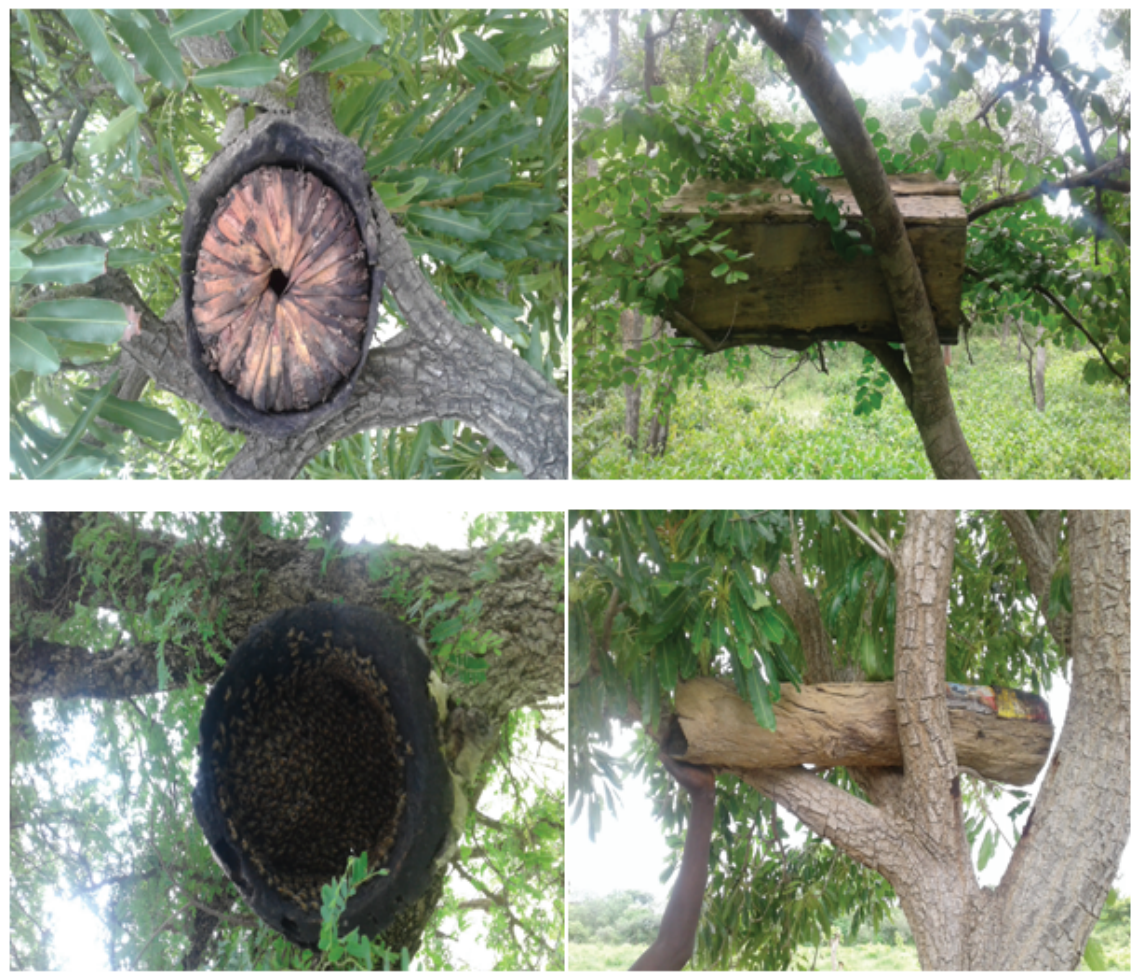

Figure 1: Various types of hives out of wooden used by the bee-keepers.

Table 3: Practical of the bee-keeping.

\begin{tabular}{|c|c|c|c|}
\hline Parameters & Answers & Labour & P.100 (\%) \\
\hline \multirow{2}{*}{$\begin{array}{l}\text { Materials used for bee- } \\
\text { keeping }\end{array}$} & Wood Trunk dug & 99 & 98 \\
\hline & $\begin{array}{c}\text { Hole of the trees and } \\
\text { basement }\end{array}$ & 2 & 2 \\
\hline \multirow{3}{*}{$\begin{array}{l}\text { Origin and nature of } \\
\text { hive }\end{array}$} & $\begin{array}{c}\text { Trunk arranged by } \\
\text { Apiculture }\end{array}$ & 83 & 82.2 \\
\hline & Order and purchase & 17 & 16.9 \\
\hline & $\begin{array}{c}\text { Hole of the trees and } \\
\text { basement }\end{array}$ & 1 & 1 \\
\hline \multirow{2}{*}{$\begin{array}{l}\text { Type of hive existing } \\
\text { the most used }\end{array}$} & Small and Average & 71 & 70.3 \\
\hline & Large & 30 & 29.7 \\
\hline \multirow{3}{*}{$\begin{array}{l}\text { Selection criteria of } \\
\text { Hive }\end{array}$} & Accessibility & 51 & 50.5 \\
\hline & Output & 31 & 30.7 \\
\hline & Resistance & 19 & 18.8 \\
\hline \multirow{4}{*}{ Site of Hive } & Orchard, roofs of box & 75 & 74.3 \\
\hline & Forest & 23 & 22.8 \\
\hline & Fields & 2 & 2 \\
\hline & Hole & 1 & 1 \\
\hline \multirow{4}{*}{$\begin{array}{l}\text { Selection criteria of the } \\
\text { site of hive }\end{array}$} & To avoid the flight & 74 & 73.3 \\
\hline & $\begin{array}{c}\text { To avoid the } \\
\text { aggressions of the } \\
\text { bees }\end{array}$ & 20 & 19.8 \\
\hline & Food availability & 4 & 4 \\
\hline & Follow-up and control & 3 & 3 \\
\hline
\end{tabular}

\section{Period, techniques, materials and product of harvests}

For $46.5 \%$ of the producers, the optimum of production out of honey was located between May and March. For the unit, the head of the household was the principal person who ensured the harvest of the products of hives. For harvest, the bee-keepers used smoked to drive out the bees and the bucket like container (Table 7).

The principal product of the hive collected was essential the broken, dark or yellow honey of white colour (Figure 2).

\section{The exploitation of product of the hive}

Honey was exclusively the product of hives it's as much as sold. The head of household is the only one which decided sale of honey that the woman sold of markets of close villages. The period going from February to May was regarded as the most favorable moment of the honey flow, which was sold by Coro (Table 8).

\section{Performance of production}

The average number of the hive was 17.21 per bee-keeper for a capacity of 4 liters on average. Thus, the annual average production was 862.72 liters, with a frequency of approximately 17 days between two harvests. The annual average quantity of sold honey was 487 liters with a price of 1676, 57 FCFA, which ensured an average annual income moreover 834 930, 69 FCFA (Table 9).

\section{Medical management}

The majority of the bee-keepers affirmed to have noted the case of mortalities in their breedings. The principal causes of mortalities were the fire used at the time of harvest, the lack of water, the predation of the lizards and ants, the rains. The period of strong mortality was between March-April and July-August when the termites, the ants, the 
lizards, the caterpillars, and the fall melliferous flowers would be the principal causes (Table 10).

The totality of the guardians declared a case of taking flight of the product hives by the unknown ones $(95 \%)$, children of the village (3\%), herdsmen (1\%) like by the children of the bee-keeper (1\%).

Table 4: Conduct of bees

\begin{tabular}{|l|c|c|c|}
\hline \multicolumn{1}{|c|}{ Parameters } & Answers & Labour & P.100 (\%) \\
\hline Person in charge led & Head of household & 101 & 100 \\
\hline \multirow{2}{*}{ Follow-up of the bees } & Yes & 100 & 99 \\
\cline { 2 - 4 } & No & 1 & 1 \\
\hline \multirow{2}{*}{ Method of Follow-up } & Control each 2 days & 61 & 60.4 \\
\cline { 2 - 4 } & oversight & 40 & 39.6 \\
\hline \multirow{2}{*}{$\begin{array}{l}\text { Nobody ensuring the } \\
\text { follow-up }\end{array}$} & Head of Household & 100 & 99 \\
\cline { 2 - 4 } & Child & 1 & 1 \\
\hline \multirow{2}{*}{ Renewal of colonies } & Yes & 75 & 75 \\
\cline { 2 - 4 } & No & 26 & 26 \\
\hline \multirow{2}{*}{$\begin{array}{l}\text { Causes of nonrenewal } \\
\text { of colonies }\end{array}$} & $\begin{array}{c}\text { Maintenance of the } \\
\text { production }\end{array}$ & 60 & 59.4 \\
\cline { 2 - 4 } & Absence of causes & 25 & 24.8 \\
\cline { 2 - 4 } & Maintenance of the colony & 16 & 15.8 \\
\hline
\end{tabular}

Table 5: Melliferous plants are used a lot of by bees.

\begin{tabular}{|c|l|c|c|}
\hline Numbers & \multicolumn{1}{|c|}{ Melliferous Plants } & $\begin{array}{c}\text { Quotations } \\
\text { (a Number of times) }\end{array}$ & P.100 (\%) \\
\hline 1 & Vitelleria paradoxa & 64 & 18.08 \\
\hline 2 & Parkia biglobosa & 45 & 12.71 \\
\hline 3 & Khaya senegalensis & 38 & 10.73 \\
\hline 4 & Daniella oliveri & 33 & 9.32 \\
\hline 5 & Prosopis africana & 25 & 7.06 \\
\hline 6 & Tamarindus indica & 22 & 6.21 \\
\hline 7 & Detarium senegalense & 17 & 4.8 \\
\hline 8 & Sorghum bicolor & 16 & 4.52 \\
\hline 9 & Mangifera indica & 15 & 4.24 \\
\hline 10 & Zea mays & 12 & 3.39 \\
\hline 11 & Gossypium herbaceum & 8 & 2.26 \\
\hline 12 & Ziziphus mauritiana & 8 & 2.26 \\
\hline 13 & Grewia bicolor & 7 & 1.98 \\
\hline 14 & Borassus aethiopicum & 7 & 1.98 \\
\hline 15 & Cucumis melo & 6 & 1.69 \\
\hline 16 & Gardenia ternifolia & 6 & 1.69 \\
\hline 17 & Ficus gnaphalocarpa & 3 & 0.85 \\
\hline 18 & Psidium guajava & 3 & 0.85 \\
\hline 19 & Moringa oleifera & 3 & 0.85 \\
\hline 20 & Piliostigma reticulatum & 3 & 0.85 \\
\hline 21 & Hibiscus vulgaris & 2 & 0.56 \\
\hline 22 & Momordica indica & 2 & 0.56 \\
\hline 23 & Hyphaene thebaica & 2 & 0.56 \\
\hline 24 & Ximenia americana & 2 & 0.56 \\
\hline 25 & Calotropis procera & 1 & 0.28 \\
\hline 26 & Hibiscus esculenta & 1 & 0.28 \\
\hline 27 & Phaseolus vulgaris & 354 & 0.28 \\
\hline 28 & Combretum micranthum & & 0.28 \\
\hline 29 & Ficus ingens & Total & \\
\hline & & 100 \\
\hline & & 1 & \\
\hline & & 28 \\
\hline
\end{tabular}

\section{The improvement constraints of production and proposals}

The principal constraints of production were the robbers and the ignorance of the food techniques. The suggestions made by the beekeepers were the fight against the robbers, their formation and the improvement of the hive (Table 11).

Table 6: Food practices.

\begin{tabular}{|l|c|c|c|}
\hline \multicolumn{1}{|c|}{ Parameters } & States & Labour & P.100 (\%) \\
\hline \multirow{2}{*}{ Type of food used } & $\begin{array}{c}\text { Flowers of the plants of } \\
\text { the area }\end{array}$ & 98 & 97 \\
\cline { 2 - 4 } & Food manufactured & 3 & 3 \\
\hline $\begin{array}{l}\text { Nature of } \\
\text { formulated food }\end{array}$ & $\begin{array}{c}\text { Cereals, onion, bean and } \\
\text { pea of ground }\end{array}$ & 101 & 100 \\
\hline $\begin{array}{l}\text { Practical of food } \\
\text { complementation }\end{array}$ & Yes & 68 & 67.3 \\
\hline $\begin{array}{l}\text { Requirements of } \\
\text { the bees }\end{array}$ & Nos & 33 & 32.7 \\
\hline Nature of & No & 95 & 94.1 \\
\hline requirement & Food & 6 & 5.9 \\
\hline
\end{tabular}

Table 7: Period, techniques, materials and product of harvests.

\begin{tabular}{|l|c|c|c|}
\hline \multicolumn{1}{|c|}{ Parameters } & Answers & Labour & P.100 (\%) \\
\hline \multirow{2}{*}{$\begin{array}{l}\text { Period when the } \\
\text { production is } \\
\text { optimal }\end{array}$} & From March to May & 47 & 46.5 \\
\cline { 2 - 4 } & From February to April & 35 & 34.7 \\
\cline { 2 - 4 } & $\begin{array}{c}\text { Between March, April, May, } \\
\text { September }\end{array}$ & 18 & 17.8 \\
\cline { 2 - 4 } & All the year & 1 & 1 \\
\hline $\begin{array}{l}\text { Nobody ensuring } \\
\text { the harvest of the } \\
\text { products of the bees }\end{array}$ & Head of household & 99 & 98 \\
\cline { 2 - 4 } Collected product & Child & 2 & 2 \\
\hline $\begin{array}{l}\text { Techniques used in } \\
\text { harvest }\end{array}$ & Use of smoke & 101 & 100 \\
\hline Material of harvest & Bucket & 101 & 100 \\
\hline \multirow{3}{*}{$\begin{array}{l}\text { Honey color at the } \\
\text { time of harvest }\end{array}$} & Broken white & 78 & 77.2 \\
\cline { 2 - 4 } & Sink & 14 & 12.7 \\
\cline { 2 - 4 } & Yellow & 7 & 6.9 \\
\hline
\end{tabular}

Table 8: Exploitation of products of the hive.

\begin{tabular}{|l|c|c|c|}
\hline \multicolumn{1}{|c|}{ Parameters } & Answers & Labour & P. 100 (\%) \\
\hline Product of hive sold & Honey & 101 & 100 \\
\hline Who decides sale & Head of household & 101 & 100 \\
\hline $\begin{array}{l}\text { Who sells honey at the } \\
\text { market }\end{array}$ & Man & 93 & 92.1 \\
\cline { 2 - 4 } Place of sale of honey & Woman & 8 & 7.9 \\
\cline { 2 - 4 } & Fare villages & 86 & 85.2 \\
\hline \multirow{2}{*}{ Favorable period of sale } & $\begin{array}{c}\text { Between February } \\
\text { and May }\end{array}$ & 15 & 14.9 \\
\hline \multirow{2}{*}{ Unit of sale used } & Koro & 100 & 100 \\
\cline { 2 - 4 } & Liter & 1 & 1 \\
\hline
\end{tabular}


Table 9: Performance of the production of honey.

\begin{tabular}{|l|c|c|c|c|}
\hline \multicolumn{1}{|c|}{ Variables } & Averages & $\begin{array}{c}\text { Standard } \\
\text { deviation }\end{array}$ & Minimum & Maximum \\
\hline Hive numbers & 17.21 & \pm 31.73 & 1 & 304 \\
\hline $\begin{array}{l}\text { Output of hive } \\
\text { (liter) }\end{array}$ & 6.13 & \pm 1.637 & 3 & 22.5 \\
\hline $\begin{array}{l}\text { Frequency of } \\
\text { production (days) }\end{array}$ & 16.91 & \pm 4.481 & 10 & 30 \\
\hline $\begin{array}{l}\text { Duration of } \\
\text { production (month) }\end{array}$ & 4.07 & \pm 1.18 & 3 & 12 \\
\hline $\begin{array}{l}\text { Quantity honey } \\
\text { produit/an (liter) }\end{array}$ & 862.72 & \pm 1859.26 & 18 & 18240 \\
\hline $\begin{array}{l}\text { Honey quantity } \\
\text { sold in liter/year }\end{array}$ & 498 & \pm 548.40 & 7.5 & 3000 \\
\hline $\begin{array}{l}\text { Average price of } \\
\text { liter (F CFA) }\end{array}$ & 1676,57 & \pm 335.078 & 1333.33 & 2000 \\
\hline $\begin{array}{l}\text { Average annual } \\
\text { income (F CFA) }\end{array}$ & $834^{\circ} 930,69$ & \pm 69155.97 & 10000 & 6000000 \\
\hline
\end{tabular}

Table 10: Medical management and constraints of production.

\begin{tabular}{|c|c|c|c|}
\hline Parameters & Answers & Labour & Percentage (\%) \\
\hline \multirow{2}{*}{$\begin{array}{l}\text { Noted mortality of } \\
\text { the bees }\end{array}$} & $\begin{array}{c}\text { Presence of case of } \\
\text { mortality }\end{array}$ & 83 & 82.2 \\
\hline & $\begin{array}{c}\text { Absence of case of } \\
\text { mortality }\end{array}$ & 18 & 17.8 \\
\hline \multirow{2}{*}{$\begin{array}{l}\text { Causes of mortality } \\
\text { of the bees }(n=18)\end{array}$} & $\begin{array}{c}\text { Fire used during } \\
\text { harvest }\end{array}$ & 9 & 50 \\
\hline & $\begin{array}{l}\text { misses water, lizard, } \\
\text { rains, Fourmis }\end{array}$ & 9 & 50 \\
\hline $\begin{array}{l}\text { Period of strong } \\
\text { mortality }(n=14)\end{array}$ & $\begin{array}{c}\text { Mars, April, July, } \\
\text { August }\end{array}$ & 14 & 100 \\
\hline Medical follow-up & Lack follow-up & 101 & 100 \\
\hline \multirow{2}{*}{$\begin{array}{l}\text { Observations of fall } \\
\text { of production }\end{array}$} & No fall of production & 58 & 57.4 \\
\hline & $\begin{array}{c}\text { Falls of production } \\
\text { observed }\end{array}$ & 43 & 42.6 \\
\hline \multirow{4}{*}{$\begin{array}{l}\text { Causes of fall of } \\
\text { production }(n=43)\end{array}$} & Termites and ants & 12 & 27.9 \\
\hline & Lézards & 12 & 27.9 \\
\hline & Caterpillars & 10 & 23.2 \\
\hline & $\begin{array}{c}\text { Falls of the melliferous } \\
\text { flowers }\end{array}$ & 9 & 20.9 \\
\hline
\end{tabular}

Table 11: The improvement constraints of production and proposals.

\begin{tabular}{|l|c|c|c|}
\hline \multicolumn{1}{|c|}{ Parameters } & Answers & Labour & Percentage (\%) \\
\hline \multirow{2}{*}{ Constraints } & $\begin{array}{c}\text { Robbers } \\
\text { Ignorance of the food } \\
\text { techniques }\end{array}$ & 45 & 51.5 \\
\cline { 2 - 4 } & Ennemis of the bees & 2 & 24.6 \\
\cline { 2 - 4 } & Misses water & 2 & 2 \\
\hline \multirow{2}{*}{$\begin{array}{l}\text { Proposal for an } \\
\text { improvement of the } \\
\text { production }\end{array}$} & $\begin{array}{c}\text { Fight against the } \\
\text { robbers }\end{array}$ & 51 & 50.5 \\
\cline { 2 - 4 } & $\begin{array}{c}\text { Training of the bee- } \\
\text { keepers }\end{array}$ & 48 & 47.5 \\
\cline { 2 - 4 } & To improve the hive & 2 & 2 \\
\hline
\end{tabular}

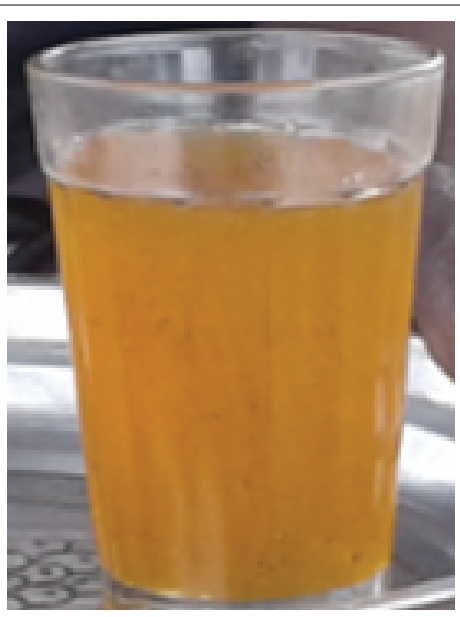

Figure 2: Collected honey color.

\section{Discussion}

The study characterized the system production of honey in the area Goundi. The results show that in this area the bee-keeping is practised mainly by the men. All the bee-keepers practise agriculture and the breeding like principal activity. The number of woman practising the bee-keeping in the area Goundi (1\%) is lower than the number of the bee-keepers women observed in Cameroun, which is 3\% [5]. This can be due to the persistence of the traditional perception for which the bee-keeping is a field exclusively reserved to the men. In case of Uganda and Mozambique, the women are more numerous in the beekeeping. In Kenya, a considerable part of the incomes of women comes from bee-keeping. The area Goundi, the bee-keeping is regarded as a significant component of the agricultural sector. Thus, the products of the bee-keeping in particular honey constitute a considerable source of income for the households. It takes place with the reinforcement and the improvement of food safety and durable agriculture like Uganda, Kenya and South Sudan [3]. These results agree with the observations made in Kenya by Omondi, et al. [6] which shows that bee-keeping generates at the sometimes socio-economic and environmental advantages. These observations are made in many the countries of sub-Saharan Africa where the bee-keeping is an activity carried out mainly on the level rural household, like generating activity of parttime incomes and food [7]. Moreover, it is crucial for agricultural wellbeing because of the natural biological interdependence generated by insects. It constitutes a means useful to reinforce the means of subsistence [7].

Contrary to the results of the studies carried out in Cameroun by Tchoumboue, et al. [5], meadows of $37 \%$ of the bee-keepers are illiterate. Moreover, most of them are not received any formation to acquire modern technical training of the bee-keeping, which is preconditions for production of honey on a large scale [1]. The lack of instruction of the bee-keepers shows all the difficulty of intensifying the breeding can constitute a handicap in the optics of popularization and the adoption of the modern apicoles techniques [5].

The totality of surveyed affirms to have practised the bee-keeping for the sale and subsistence farming. Our similar results with the observations made in the zone of Adamaoua in Cameroun [8]. In the area of Goundi, the bee-keepers exploit 3 indigenous species of small size identifiable by their aggressiveness $(52 \%)$ and/or by their form 
and their wings (35.6\%). The choice for one or the other species is guided by the output of the bees. To install them in the hives, the beekeepers to get fire wax in the hive, or by using perfume or wild onion. The site of the hive is a function of the food availability and its aptitude to avoid the case of flight and the aggressiveness bees.

Inquired affirm, that the three species bees are all aggressive. These results corroborate with the observations made by Cosmas $\mathrm{AB}$ [9] regard that the African bees are described as very defensive with the biting is painful what makes their difficult management.

Our observations show that the colonies of bees are placed on the level of orchard, roofs of the box, forest, fields, and trees during all the year. Conversely, in Cameroun [5], the installation of the hives takes place between January and March whereas with benign [10] the placement of the hives is realized in two periods, between February at April in dry season and between September and mid-November to rain season.

The number of hives of 17,28 per bee-keeper observed, of exclusively traditional type is higher than the number of hives noted with Benign $(14,48)$ by Yédomonhan et al. [1]. On the other hand, this number of hives remains lower than that observed in the west of Cameroun, which is of 42 hives [5] of which $62.2 \%$ of hives are improved types. The near-total of the bee-keepers of the zone of Goundi uses traditional hives made up of hollow tree trunk and hole of tree. The most used tree trunks are Prosopis africana, Tamarindus indica, Vitellaria paradoxa which are used as hive and the sheets of Grewia Bicolo R are used to make the cover. This practice clearly indicates modern technical the training and lack of training relating to the apicole breeding.

The nature of materials used as hive (deadwood trunk, hole in the ground, etc.) as their low output (6.13 liters) shows that the method of practised production is rudimentary. However, the cost of the material and its unavailability constitute the principal factors determining the method of production. The results of the studies carried out in the South of Kenya by Muriuki, [11] show that $75.6 \%$ of the surveyed bee-keepers use to the traditional method and $24.4 \%$ fact resort the modern technique.

Concerning the food practice, the bees nourish natural flowers and nectars of the trees of the zone. Only one minority of the bee-keepers (3\%) distribute food manufactured whereas the majority does not practise the food complement.

The head of household is the person in charge of the control of the breeding and he decides harvest as well as sale of honey on the markets. Moreover, it ensures the follow-up of the ruchers which is carried out under control and of cleaning.

The harvest of honey is carried out approximately twice per month. The frequency between two harvests is approximately 17 days. On the other hand, elsewhere it was announced that harvest is carried out once in a year. The bringing together between two harvests would be due to the low capacity of the hives of the traditional type used whose capacity seldom does not exceed the 4 liters. On the other hand, in other countries, the hives are adapted better to contain more honey. Beyene, et al. [12], note that the use of hives improved combined with better practices of management can increase the honey yield and produce honey of better quality compared to the traditional hive. The studies carried out by these authors showed that honey the average yield of the modern hive $(23,18 \mathrm{~kg} / \mathrm{hive})$ is higher than mixed hive $(13.88 \mathrm{~kg} / \mathrm{hive})$ which was in its turn significantly higher than traditional hive $(6.08 \mathrm{~kg} /$ hive $)$.
Our observations show that the honey period or harvest is carried out at the majority of surveyed between March and May (46.5\%), between February and April for 34\% also corresponds to an optimum of output. These results are similar to those observed with the Cameroun West by Tchoumboué, et al. [5].

In the zone of study, our observations show that honey is the only product of hives sold with the level of local markets. The quantity of produced honey is about 862.72 liters per annum and by bee-keeper among whom 500 liters are sold at an average price of approximately 1676,57 F.CFA thus getting an annual average income gross about 834 930,69 F.CFA per bee-keeper. On the other hand, in Cameroun $[5,13]$ with benign [10] in addition to honey, the bee-keepers sell wax, the propolis, pollen, and the royal jelly.

The bee-keeping is regarded as a potential economic activity [14]. Thus, our observations show that the gross income drawn from sale of honey is higher than the observations made in Benin which is about $237037 \pm 159167 \mathrm{~F}$.CFA/an/apiculture where the rough annual receipt by bee-keeper or grouping varies from 9000 to 580000 FCFA [10]. In this country, the rate of marketing is $90 \%$ on average and the generated gross earnings amount to $155000 \mathrm{~F} / \mathrm{an}$ /apiculture [1].

The same observations are made Uganda, Kenya and South Sudan where the honey and the other products of the hive contribute to the generation of incomes in these countries [3].

The various receipts generated by the marketing of products of the bee-keeping show with sufficiency its undeniable economic role in the reduction of poverty through the satisfaction of the needs for the households. In Ethiopia, the Government and certain ONG are engaged for the promotion of the bee-keeping like a tool to reduce poverty [15].

Concerning medical management, our results show that in these cases of mortality are seldom noted (only by $17.8 \%$ of the bee-keepers). On the other hand, to Kenya, the study carried out in eight agroecological zones announced the presence of Nosema microsporidia [16]. In Tunisia, a case of parasites was also announced [17] and of the parasite-ravageurs were observed in the democratic Republic of Congo [18].

Being the constraints, the results of our study show that the flight and the ignorance of the food techniques of formulation constitute the major production constraints.

\section{Conclusion}

This study is undertaken with the aim of better knowing the socioeconomic and technical characteristics of apicole production. It arises from this study, the bee-keeping plays a social and economic role very significant. It is practised in a traditional way by the men and its product is intended primarily for the sale and subsistence farming. Thus, the study emphasizes the principal characteristics of the producers, the materials used, the techniques of breeding, the medical practices as well as the constraints of the productions of the bee-keeping practised in the zone of Goundi. The results indicate that in this zone the beekeeping has a great potentiality to regards production of honey and gets significant monetary incomes with the bee-keepers. Moreover, the products of rucher (honey) contribute to food self-sufficiency and the food safety of rural households. Unfortunately, the beekeeping is practised in a traditional way and suffers from several handicaps among which lack of technical training. Although the bee-keepings use traditional techniques and materials not adapted to weak capacity, the monetary incomes resulting from this activity are very appreciable. 
The socio-economic importance of the bee-keeping through the sale of honey highlighted the interest of the development of this breeding to improve the income of the producers.

The production is increasing necessary by the intensification of the production through the framing and the training, the adoption of modern hives and the support of the bee-keepers.

\section{References}

1. Yédomonhan $H$, Akoègninou $A$ (2009) La production du miel à Manigri (Commune de Bassila) au Bénin: enjeu et importance socioéconomique. Int J Biol Chem Sci 3: 125-134.

2. Maus CH, Alix A, Castle D, Coulson M, Cuffe J, et al. (2016) Assessing the use of crop protection products for potential risks to honey bees. Bull Anim Health Prod Afr 64: 57-72.

3. Ashjan PE (2016) Honey Residues Monitoring, Samples Collected from three of the East African's Countries (Uganda, Kenya, And South Sudan) Markets. Bull Anim Health Prod Afr 64: 77-82.

4. Zafack J (2016) Des dispositions responsables à prendre pour la protection des abeilles contre les effets néfastes des pesticides. Bull Anim HIth Prod Afr 64: 73-76.

5. Tchoumboue J, Tchouamo IR, Pinta JY, Mambou NN (2001) Caractéristiques sosio-éconmiques et techniques de l'apiculture dans les hautes terres de l'Ouest du Cameroun. Tropicultura 19: 141-146.

6. Omondi Al, Affognon HD, Kingori WS, Diiro MG, Muriithi BW, et al. (2016) Analysis of farm household technical efficiency in small-scale beekeeping enterprise in mwingi and kitui, kenya. Bull Anim Hlth Prod Afr 64: 193-206.

7. James M (2016) The status and future prospects of honeybee production in africa. Bull Anim HIth Prod Afr 64: 169-182.

8. Founadoudou (2007) Caractéristiques socio-économiques et techniques de l'Apiculture de la zone Soudano-Guinéenne de I'Adamaoua (Cameroun). Mém Ing Agro Fac Agro Univ de Dschang 85.
9. Cosmas $A B$ (2016) A review of african honeybees, behaviour and potential for increased beekeeping production and food security. Bull Anim HIth Prod Afr 64: 183-191.

10. Ahouandjinou STB, Yedomonhan $\mathrm{H}$, Adomou AC, Tossou MG, Akoegninou A (2016) Caractéristiques techniques et importance socio-économique de l'apiculture au Nord-Ouest du Bénin : cas de la commune de Cobly. Int J Biol Chem Sci 10: 1350-1369.

11. Muriuki J (2016) Beekeeping technology adoption in arid and semiarid lands of southern kenya. Bull Anim HIth Prod Afr 64: 217-223.

12. Beyene T, Abi D, Chalchissa G, Mekonen Woldatsadik M (2016) Evaluation of transitional and modern hives for honey production in the mid rift valley of Ethiopia. Bull Anim HIth Prod Afr 64: 157-165.

13. Fotso Kenmogne PR, Meutchieye F, Andriamanalina SI, Youbissi A, Tchoumboué J, et al. (2014) Caractéristiques socio-économiques et techniques de l'apiculture dans les Départements de Bamboutos, Mifi et Menoua (Région de l'Ouest-Cameroun). Livestock Research for Rural Development 26.

14. Tsafack Matsop AS, Muluh Achu G, Kamajou F, Verina I, Vabi Boboh M (2011) Etude comparative de la rentabilité de deux types d'apiculture au nord ouest Cameroun. Tropicultura 29: 3-7.

15. Teweldemedhn G (2016) Honeybee colony marketing and its implications for queen rearing and beekeeping development in werieleke district, Northern Ethiopia. Bull Anim HIth Prod Afr 64: 87-101.

16. Wanjama JK, Onyango I, Mutyambai DM, Kabochi SK, Ndegwa PN (2016) Occurrence of Nosema species in honey bee colonies in Kenya. Bull Anim HIth Prod Afr 64: 129-135.

17. Faten BA, Naima B (2016) Évaluation des ruches de transition et des ruches modernes pour la production de miel dans la mid rift valley de l'Éthiopie. Bull Anim HIth Prod Afr 137-142.

18. Munyuli TMB, Rubabura D, Kana C, Batumike S (2016) Preliminary observations on enemies of stingless bees and honeybee (Apis mellifera adansonii I.) Colonies from the miti-civanga-tshibinda sector East of Kahuzi Biega national park, South-Kivu province, Eastern DR Congo. Bull Anim HIth Prod Afr 64: 143 -156. 